Relations industrielles

Industrial Relations

\title{
Confrontation at Winnipeg : Labour, Industrial Relations and the General Strike, by David Jay Bercuson, Montreal, McGill-Queen's University Press, 1974, 227 pp.
}

\section{Gary N. Chaison}

Volume 30, numéro 1, 1975

URI : https://id.erudit.org/iderudit/028600ar

DOI : https://doi.org/10.7202/028600ar

Aller au sommaire du numéro

Éditeur(s)

Département des relations industrielles de l'Université Laval

ISSN

0034-379X (imprimé)

1703-8138 (numérique)

Découvrir la revue

Citer ce compte rendu

Chaison, G. N. (1975). Compte rendu de [Confrontation at Winnipeg : Labour, Industrial Relations and the General Strike, by David Jay Bercuson, Montreal, McGill-Queen's University Press, 1974, 227 pp.] Relations industrielles /

Industrial Relations, 30(1), 129-130. https://doi.org/10.7202/028600ar

Tous droits réservés @ C Département des relations industrielles de l'Université Laval, 1975
Ce document est protégé par la loi sur le droit d'auteur. L’utilisation des services d'Érudit (y compris la reproduction) est assujettie à sa politique d'utilisation que vous pouvez consulter en ligne.

https://apropos.erudit.org/fr/usagers/politique-dutilisation/ 
L'auteur présente d'abord la sociologie comme discipline et explicite quelques notions fondamentales (interaction, communication, groupe, statut, rôle), nécessaires à l'intelligence de l'analyse qu'il se propose de faire. Les principales méthodes de recherche utilisées par les sociologues sont, aussi, brièvement présentées.

Le lecteur est, dès lors, prêt pour une analyse de la vie en milieu hospitalier. Cette analyse met spécialement l'emphase sur l'importance des communications et des relations interpersonnelles au sein de l'organisation hospitalière. L'auteur étudie successivement les rôles de malade, de médecin, d'infirmière et d'administrateur pour tenter d'éclairer les rapports complexes que nouent quotidiennement ces diverses catégories de personnes.

Cette approche, de type fonctionnaliste, a le mérite de rendre compréhensibles les comportements individuels en milieu hospitalier. Cependant elle comporte d'importantes limites, entre autres, celle de ne pas tenir compte de variables structurelles majeures. Par exemple, l'organisation formelle de l'hôpital y est tenue pour valeur négligeable; de même l'auteur ignore-t-il, en s'en tenant à une analyse des rôles et des statuts, l'importance des rapports de force entre les différents groupes professionnels impliqués dans le processus de distribution des soins hospitaliers pour expliquer la nature des relations entre les professionnels de la santé (médecin-infirmière, par exemple). En somme, on a parfois l'impression qu'il estime que le fonctionnement harmonieux de l'hôpital ne tient qu'à l'établissement de relations interpersonnelles cordiales entre les individus qui y vivent et $\mathrm{y}$ travaillent.

Cela dit, l'ouvrage de Swertz mérite d'être bien reçu; la formule de «l'ouvrage d'initiation », s'adressant à une catégorie spécifique d'individus implique nécessairement une certaine dose de simplification et de réductionnisme, avec tous les dangers que cela suppose. De ce côté, Swertz s'en tire bien. L'analyse qu'il fait de l'hôpital reste partielle, mais elle est claire et compréhensible; les professionnels de la santé y trouveront leur profit.

Université Laval
Confrontation at Winnipeg : Labour, Industrial Relations and the General Strike, by David Jay Bercuson, Montreal, McGill-Queen's University Press, 1974, 227 pp.

The general strike is a rare event and an extraordinary display of class polarization and trade union unity. Its widespread effect could tempt an observer to concentrate on the drama of the strike while neglecting the events leading up to it. The author of this volume has carefully avoided the error of viewing the general strike as merely the relationship between the parties from the time of negotiations until the eventual return to work. His examination of the Winnipeg general strike is accomplished with a full realization of the importance of the deteriorating labour-management relations of the prior decades. In large part, this is a study of the pressures and frustrations leading to the climatic confrontation in 1919.

More than one half of this volume is devoted to a review of the often volatile labour relations climate in Winnipeg. The initial chapter describes the early years of rapid economic expansion and the emerging municipal-industrial relationship. Intensified employer resistance to union recognition and bargaining is seen in the chapters on the depression of 1913-15 and the wartime years. Emphasis is placed on the growing frustration of workers and their unions when faced with rising living costs and a generally hostile employer reaction to their bargaining efforts. Employer resistance was widespread among the city's contract metal-working shops, particularly in comparison to the more cooperative relationships characterizing the building trades and the running trades of the railroads.

In later chapters, a series of negotiations and disputes begin to shape a collision course between trade unions and the city's employers. A worsening of labour-management relations led the unions to coordinate their efforts through sympathy strikes. The failure of a contract shop strike expanded the influence of the radical within the Winnipeg Trades Council. Moreover, workers throughout the West began to display a pronounced dissatisfaction with the more conservative among their leaders. This surge of employee mili- 
tancy was intensified by the widespread discontent among the returning veterans.

The increased attractiveness of radical solutions to work related problems was exemplified the Western Labour Conference's acceptance of the principles of the One Big Union and industrial unionism. The setting for a massive confrontation was completed when an impasse was reached in negotiations between the metal trades unions and the contract shops. The refusal of the employers to negotiate with a multiunion committee and the loss of confidence by the unions in the constructive role of the government seemed to lead almost inevitably to as drastic a measure as the general strike.

The events of the general strike are described in three chapters. The coordinating role of the Cenral Strike Committee is detailed along with the organized opposition from the Citizen's Committee. Particular emphasis is placed on the provincial and municipal government's view that the strikers had taken revolutionary action through their usurpation of civil authority. A separate chapter describes the defeat of the strike and the disarray within the strike committee when its more radical leaders were imprisoned. Continued government and employer efforts to resume operations led to rioting and the assertion of authority by the RNWMP, military and special police.

In his final chapter, the author deals with factors contributing to the defeat of the dispute and evaluates the role of the general strike within organized labour's arsenal of political and industrial weapons. It is concluded that the Winnipeg strikers were not revolutionaries and has mistakenly underestimated the political impact of their actions. Filled with the righteousness of their cause the strikers had overcommitted themselves and their control of essential services tended to align the interests of the government with those of the employers. It is further stressed that the Winnipeg general strike was neither a Bolshevik attempt to overturn constituted authority nor a mass campaign for industrial unionism. Rather, it was a unified attempt to both force intransigent employers to accept the legitimacy of multi-union negotiations and pressure the government to pass protective labour legislation.

The author of this study has succeeded in exposing the sources of the frustration so strongly felt by Winnipeg's workers and unions in 1919. He has presented us with more than just a case study of a general strike that failed. $\mathrm{He}$ has traced the desperation leading to the general strike and has considered the dispute's political and industrial implications.

Some readers might find fault with the scope of the analysis. Additional detail could have been provided in regard to the relationship between pro and anti-strike veterans or the activities of major immigrant groups. Perhaps greater attention could have been paid to the federal government's reaction to the strike as well as relationship between federal, provincial, and municipal authorities. However, these points are of minor significance in view of the main contribution of this work. In a brief and well written volume the author has illuminated the background to North America's major general strike. His work should appeal to a general audience as well as specialists in areas of history and industrial relations.

Gary N. CHAISON

University of New Brunswick 